\title{
Improvement of the Geotechnical Properties of the Soil of Lime-Treated Cubitermes Mound Soil
}

\author{
Séverin Jean Maixent Loubouth ${ }^{1,2}$, Louis Ahouet1,3, Raymond Gentil Elenga ${ }^{*}$, \\ Sylvain Ndinga Okina1,2, Paul Louzolo Kimbembe ${ }^{4}$
}

\author{
${ }^{1}$ Laboratoire des Matériaux et Energies, Faculté des Sciences et Techniques, Université Marien Ngouabi, Brazzaville, Congo \\ ${ }^{2}$ Ecole Nationale Supérieure Polytechnique, Université Marien Ngouabi, Brazzaville, Congo \\ ${ }^{3}$ Bureau de Contrôle du Bâtiment et Travaux Publics, Brazzaville, Congo \\ ${ }^{4}$ Ecole Normale Supérieure, Université Marien Ngouabi, Brazzaville, Congo \\ Email: *rgelenga@gmail.com
}

How to cite this paper: Loubouth, S.J.M. Ahouet, L., Elenga, R.G., Okina, S.N. and Kimbembe, P.L. (2020) Improvement of the Geotechnical Properties of the Soil of Lime-Treated Cubitermes Mound Soil. Open Journal of Civil Engineering, 10, 22-31. https://doi.org/10.4236/ojce.2020.101003

Received: November 9, 2019

Accepted: January 28, 2020

Published: January 31, 2020

Copyright (c) 2020 by author(s) and Scientific Research Publishing Inc. This work is licensed under the Creative Commons Attribution International License (CC BY 4.0).

http://creativecommons.org/licenses/by/4.0/

\section{(c) (i) Open Access}

\begin{abstract}
This work consisted in determining the geotechnical properties of the soil of the Cubitermes termite mound soil treated with lime for use in road construction in accordance with the relevant standards. The raw soil is composed of $29.45 \%$ clay, $45.12 \%$ silt and $25.43 \%$ sand, and its granulometric curve is above the relevant standard curve. The addition of lime up to $9 \%$ decreases the fine fraction content from $75 \%$ to $60 \%$, and the maximum dry density from $1.62 \mathrm{t} / \mathrm{m}^{3}$ to $1.36 \mathrm{t} / \mathrm{m}^{3}$. The reduction of the fine fraction should reduce the soil sensitivity to water, and the emission of dust from the road. The compressive strength of the raw soil (3.89 MPa) is higher than that of most cohesive soil, and is probably one the causes of the longevity of the rural road paved with this soil. Treated soil with $6 \%$ in lime content has the highest compressive strength (5.95 MPa), and the lowest deformation at failure. Until 28 days, the improvement of the compressive upon the curing time is almost the same for untreated and treated termite mound soils. Thus, this improvement could be mostly attributed to the drying of the samples instead to the pozzolanic reactions. Besides, adding lime also enhances the shear strength of soil. Therefore, adding lime up to $6 \%$ in content to the termite mound soil should improve its behavior as surface roads.
\end{abstract}

\section{Keywords}

Cubitermes Mound Soil, CEBTP 1980, Unpaved Roads, Geotechnical Properties 


\section{Introduction}

Earth is the most worldwide used material in construction for thousands of years. In the Republic of Congo, unpaved roads represent $20,123 \mathrm{~km}$, that is $86.61 \%$ of the road network (National Development Plan 2018-2022) [1]. The cost of the road construction and maintenance is recognized to be one of the major hindrances to the development of the road network in developing countries [2] [3]. The use of appropriate local materials should contribute to reducing this cost and the environmental impact of road construction [4] [5] [6]. Unfortunately, natural suitable soils for road purposes are not widespread, and sometimes the cost to transport them far from their deposit is prohibitive. That is why, in some African areas, the scarcity of suitable conventional road materials had led to the use of unconventional materials such lateritic soils or termite mound soils as roads and landing strip pavements [5] [6] [7] [8]. These materials have shown good performance, even in some case the properties of lateritic soils do not comply with traditional standards [5] [6] [8] [9]. For instance, in 2005, the World Bank has financed the pavement of the road Ngo-Mpouya $(65 \mathrm{~km})$ in Republic of Congo with the Cubitermes mound soil. This pavement lasted nearly three years instead of one year for the ordinary soils. These applications of termite mound soils were not preceded by deep laboratory tests, but were motivated mostly by the availability of the material. It would be interesting to know whether the properties of termite mound soils comply with the conventional specifications for these applications.

The life span of the road paved with the termite mound soil could be further extended. Indeed, in the dry season, these roads release clouds of fine particles. Their departure damages the skeleton and the cohesion of the pavement, and thus the road surface undulates. On the other hand, in the rainy season, the road becomes a little muddy, and vehicles create ruts. This behavior also suggests an excess of fine particles in mound soils. Indeed, it is the fine fraction of the soil (clay and silt) that is responsible for water absorption. When the moisture content increases, the clay swells and becomes plastic. The clay fraction is the binder in the soil, but its excess makes the soil very sensitive to water and generates cracks in the pavement. Many studies have shown that the clay content in termite mound soils is generally higher than in their surrounding soil [10] [11]. This high clay content contributes to enhancing the compressive strength and the resistance to rainfall of termite mounds. Indeed, a termite mound, even uninhabited, can withstand these rains for decades.

To limit the formation of sludge and ruts, the road is raised with a thick embankment and the traffic is stopped after heavy rain. These measures generate additional costs (navvying costs, and barrier guard earnings). However, nothing has yet been done to limit the dust generation in the dry season. Reducing the fines content of these soils should attenuate these two problems, and therefore it should extend the life span of these pavements.

On the other hand, numerous studies had shown that the treatment with lime 
flocculates particles and may enhance its mechanical properties through exchange cations and pozzolanic reactions [12] [13] [14] [15]. The effectiveness of the lime treatment depends on several factors, and particularly on the soil texture and mineralogical composition, the clay type and content, the lime content, the curing duration and temperature [15] [16] [17]. This diversity of factors is probably the cause of some contradictory results in the literature. For example, depending on the study, the optimal lime content varies from $3 \%$ to $10 \%$. That is why, for each soil, the optimal conditions must be determined by appropriate tests. To our knowledge, the effect of lime on the properties of a termite mound soil has not yet been studied.

The objective of this work is to determine the geotechnical characteristics of the Cubitermes mound soil treated with lime for use in road construction. These characteristics will be compared with the specifications of the CEBTP 1980 [18] used in most African countries.

\section{Materials and Methods}

The Cubitermes mounds were collected along the Ngo-Mpouya road in Congo, around the village at $5^{\circ} 45^{\prime}$ East and $2^{\circ} 29^{\prime}$ South. They are mushroom-shaped and have on average $30 \mathrm{~cm}$ in diameter and $30-50 \mathrm{~cm}$ in height. After collection, the termite mounds were crushed as for their use as a road surface. After crushing, the soil was sieved to retain only grains with a diameter inferior to 2 $\mathrm{mm}$. The hydrated lime of the type "CL 90-S" was purchased in the local market. The mixtures of soil-lime at $0 \%, 3 \%, 5 \%, 6 \%, 6 \%, 7 \%$ and $9 \%$ by dry mass of sieved soil were prepared by stirring thoroughly the sieved soil and lime until the mixtures were homogenized.

The soil granulometric analysis was carried out following the NF P94-056 and NF P94-057 standards. The mixtures were analyzed after $48 \mathrm{~h}$ of the cure. To estimate the soils' plasticity, the methylene blue test was conducted according to NF P 94-068 standard.

The maximum dry density (MDD) and the optimum moisture content (OMC) were determined by the modified Proctor test as specified in the standard NF P94-093.

Compressive tests were performed on cubic specimens of $4 \times 4 \times 4 \mathrm{~cm}^{3}$ molded at the optimum moisture content for all soil-lime mixtures, and cured at room temperature $\left(25^{\circ} \mathrm{C}\right.$, on average) for duration of $3,7,14,21$, and 28 days. For each duration and soil-lime ratio, six specimens were made and tested on the IGM Universal press accordingly to the standard NF P98-230-2.

The shear tests were carried out on undrained samples for all lime-soil mixtures at $12 \mathrm{~h}$ of curing. The samples were prepared by compaction in the conditions of the modified Proctor test optimum. Three normal stress levels were used, and for each lime-soil ratio and normal stress level, three tests were realized to ensure the reliability of the results. The shear stresses were measured using a Casagrande box as specified in the standard NF P94-071-1. 


\section{Results and Discussion}

\subsection{Geotechnical Properties of the Raw Cubitermes Mound Soil}

The grain size analysis (Figure 1) showed that the maximum grain size of the crushed mound soil is $1 \mathrm{~mm}$. Thus, it complies with the specifications of the CEBTP 1980 which sets the minimum and maximum grain size at 0.5 and 10 $\mathrm{mm}$, respectively. As indicated by the road surface behavior during the field experiment, the Cubitermes mound soil has too much fine particles. Indeed, the percentage of grains with a diameter inferior to $80 \mu \mathrm{m}$ (fine fraction) is $75 \%$. This value is above the maximum recommended by the CEBTP 1980. The OMC of this soil is of $19.65 \%$, while the maximum value set by the CEBTP 1980 is of $13 \%$. This higher OMC value is in agreement with the high fines content since the fine fraction of the soil (silt and clay) is responsible of its capacity to absorb water. The maximum dry density of this soil is $1.56 \mathrm{~g} / \mathrm{cm}^{3}$, below the minimum of $1.90 \mathrm{~g} / \mathrm{cm}^{3}$ specified by the CEBTP 1980 . This low density compared to standards can also be explained by the excess of the soil fine fraction. Indeed, better the soil is graduated, higher is its density.

On the other hand, the CMS methylene blue value (0.25) and plasticity index (17\%) are in the ranges recommended by the CEBTP 1980 standards, $0.2-1.25$ and $10 \%-30 \%$, respectively. Overall, the termite mound soil geotechnical properties do not comply with CEBTP 1980 standards. However, it performs better than most ordinary soils. This disagreement between the behavior in the field and the standard previsions was already observed for some lateritic soils. Therefore, it is necessary to redefine these standards to conform them to the experimental results, as for the lateritic soils [9] [19] [20].

\subsection{Geotechnical Properties of the Cubitermes Mound Soil-Lime Mixtures}

For soil-lime mixtures, the fine fraction percentage decreases gradually from $75 \%$ to $60 \%$, with increasing lime content from $0 \%$ to $9 \%$. The minimum value reached remains higher than the maximum prescribed by the standard. The decreases in the fines content can be explained by the flocculation of the clay particles due to the replacement of the monovalent ions by the $\mathrm{Ca}^{2+}$. This phenomenon improves the workability of the soil and should reduce dust generation during the dry season, and water sensitivity during the rainy one.

Figure 2 shows the evolution of the Proctor curve of the soil-lime mixture with the increase in lime content. Firstly, it can be noticed that the Proctor curve becomes flatter with the increase in lime content. This result indicates that the lime treatment reduces the termite soil sensitivity to water. Secondly, increasing lime content up to $9 \%$, increases the optimum moisture content (OMC) from $20 \%$ to $24.8 \%$, and decreases the maximum dry density (MDD) from $1.62 \mathrm{~g} / \mathrm{cm}^{3}$ to $1.36 \mathrm{~g} / \mathrm{cm}^{3}$. The OMC increase seems contradictory to the reduction of fines content reported above, but it could be attributed to the additional water required for the hydration of lime, the cation exchange and pozzolanic reactions in 


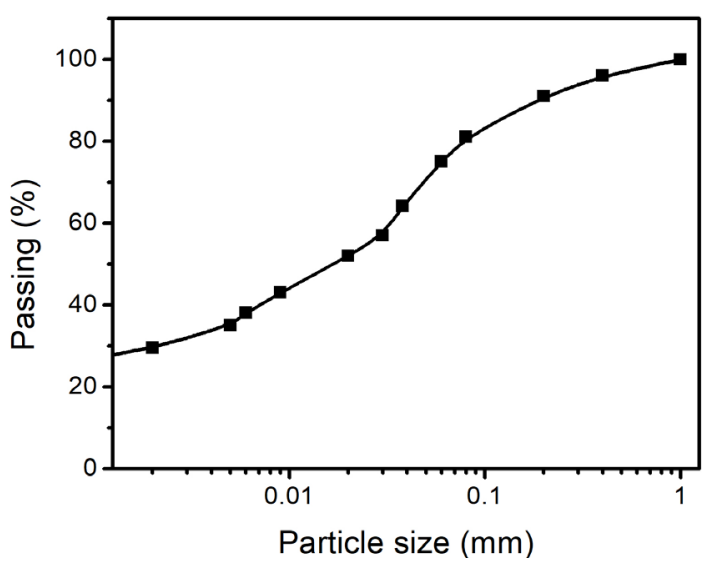

Figure 1. Particle size distribution of a raw Cubitermes mound soil.

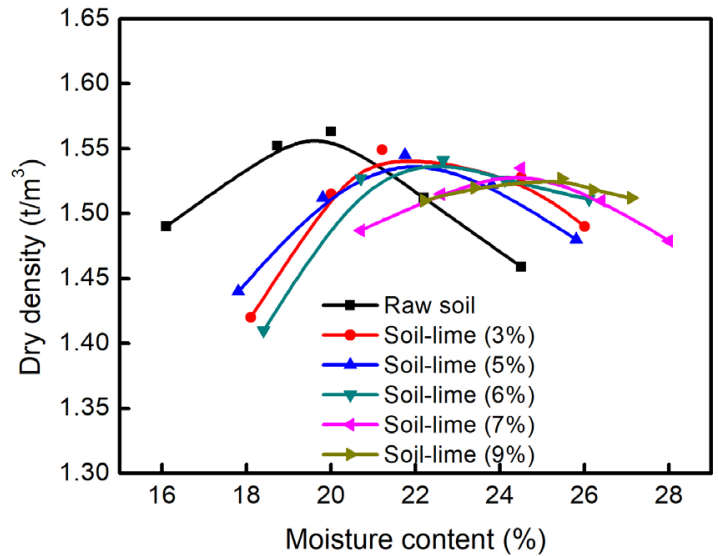

Figure 2. Effect of adding lime to a Cubitermes moul. Whith the increasing of the lime content, the maximum dry density and the water sensitivity decrease, while the optimum water content increases.

the soil-lime mixture [15] [21] [22]. The decrease of the MDD is due, on the one hand, to the formation of aggregate particles, and on the other to the replacement of the soil by lime which is lighter. These results are analogous to those reported in previous studies, although the amplitude of the variation is not the same [12] [21] [22] [23].

\subsection{Mechanical Properties of the Cubitermes Mound Soil-Lime Mixtures}

Figure 3 reports the evolution of the compressive strength with the lime content of soil-lime mixtures cured during times ranged from 3 days to 28 days. These results showed that with the increase of lime content, and at all curing times, the maximal compressive strength is reached for a lime content of about $6 \%$. At 28 days of curing, the compressive strength increases from 3.89 MPa for untreated soil, to $5.95 \mathrm{MPa}$ for soil treated with $6 \%$ of lime content, that is, an increase of 
about $53 \%$. From $6 \%$ to $9 \%$ of lime content, the compressive strength decreases from 5.95 $\mathrm{MPa}$ to $4.58 \mathrm{MPa}$, and thus it remains higher than that of the untreated soil. This evolution of the compressive strength was already observed for ordinary clayey soils treated with lime [12] [15]. From $0 \%$ to about $5 \%$ of lime content, the increase in compressive strength of the mixture is attributed to the formation of cementitious compounds during the soil-lime reactions, namely the calcite, the carbonate silicate hydrate and the portlandite [12] [15]. According to Millogo et al., for higher lime concentrations, a lime fraction reacts with the atmospheric carbon dioxide, and this carbonation limits the formation of cementitious compounds [24].

Moreover, for all mixtures, up to 28 days, the shape of the compressive versus the curing time is nearly linear (Figure 4). Many studies attributed the improvement of the compressive with the curing time to the pozzolanic reactions occurred in the soil-lime mixture. But the similarity of the shape of the curve of untreated soil and that of the treated soils indicates that these reactions are not the main cause of this improvement until 28 days. Thus, this improvement with the curing time can be mainly attributed to the drying process. From 3 days to 28 days of curing, the compressive strength of the raw soil varies from $2.16 \mathrm{MPa}$ to $3.89 \mathrm{MPa}$. All these values are above the range of the compressive strength of coherent soils reported by Bruce [25].

If the lime treated pavement layer is on a deformable substrate and is relatively thin (which is generally the case on economic roads), it works mainly with imposed deformation. Figure 5 shows that there is a strong negative correlation between the compressive strength and the deformation to failure of the mound soil-lime mixture. The deformation to failure decreases when the compressive increases, that is, up to $6 \%$ in lime content, the deformation to failure decreases, and beyond this lime content, it increases. Therefore, it is necessary to use this soil-lime mixture on a more rigid substrate to limit cracks.

Figure 6 represents the evolution of shear strength of the soil-lime mixtures with the normal stress. These tests were conducted at $12 \mathrm{~h}$ of the curing time. The results showed that at this curing time, the lime treatment is not very effective. Except the treated soils with $6 \%$ and $9 \%$ in lime content, the shear strength of soil-lime mixture is slightly higher than that of raw soil. Most studies on the effect of lime content on the shear stress were carried out beyond 3 days of curing. They revealed that the shear stress increases with the increase of the curing time due to the pozzolanic reactions, and its maximum is reached around $5 \%$ in lime content. On the contrary, after one day of curing, the effect of adding lime on the shear stress varies greatly with the soil. Youssef et al. [23] reported an improvement of the shear stress up to $6 \%$ in the lime content, while Sharma et al. [22] reported a steady decrease in shear strength of a lime treated mountain soil at 1 day of curing with the increase of the lime content. Our results are more closed to those of Youssef et al. [23] than to those of Sharma et al. [22]. 


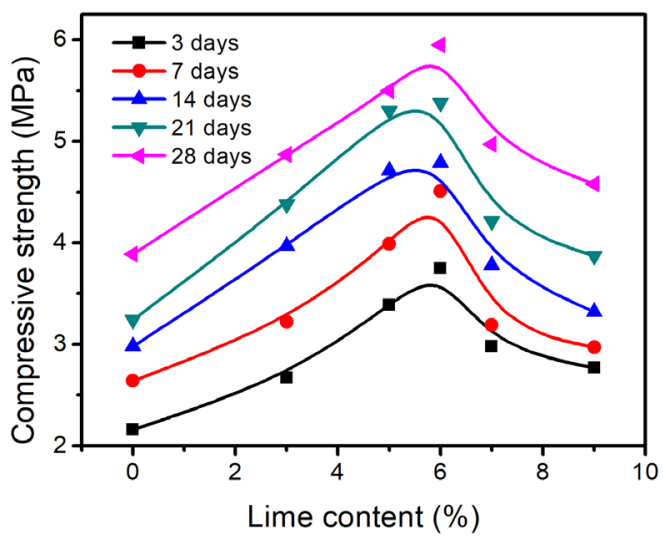

Figure 3. Evolution of the compressive strength of the treated Cubitermes mound soil with the lime content at curing times ranged from 3 days to 28 days. For all curing times, the maximum compressive strength is reached at about $6 \%$ in lime content.

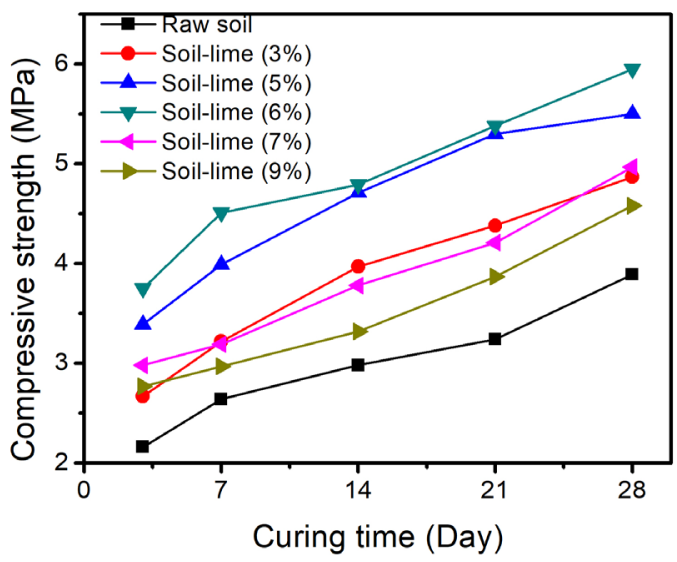

Figure 4. Evolution of the compressive strengths of lime-mound soil mixtures with the curing time. From 3 days to 28 days, the lime content has not a significant effect on the rate of the improvement (all the curves are nearly parallel).

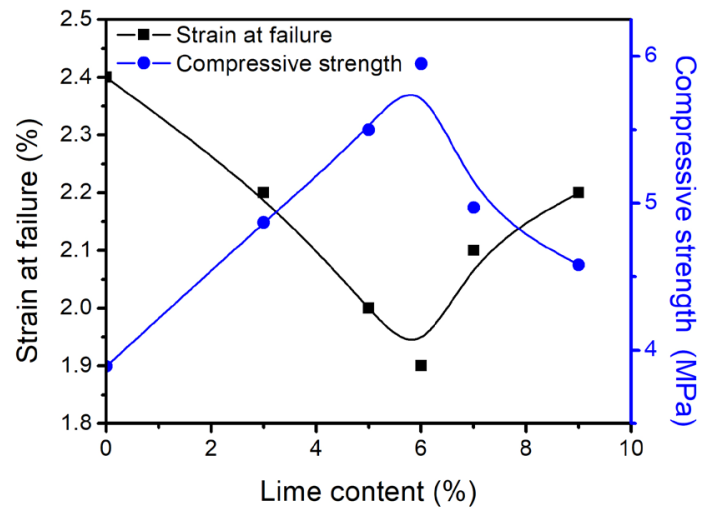

Figure 5. At 28 days of curing, effet of the lime conent on the compressive strength and the deformation to failure of lime-treated Cubitermes mound soil. 


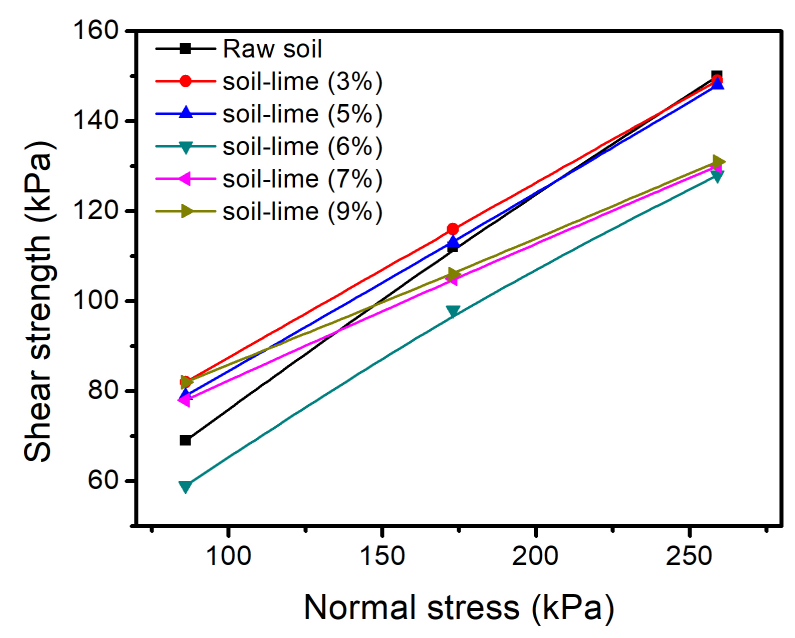

Figure 6. Shear stresses of the lime-Cubitermes mound soil mixtures for lime contents ranged from $3 \%$ to $9 \%$.

\section{Conclusion}

The aim of this study was to assess the effect of lime treatment on the properties of a termite mound soil which is used as pavement for rural roads. The results showed that the raw soil is composed of $29.45 \%$ clay, $45.12 \%$ silt and $25.43 \%$ sand, and its granulometric curve is above the relevant standard curve. This high amount of the fine fraction explains the formation of ruts and dust observed on the road. The incorporation of lime decreases the soil sensitivity to water by reducing its fine fraction content. Thus, adding lime should limit the formation of ruts and dust. The compressive strength of untreated soil is of $3.89 \mathrm{MPa}$. This value is higher than that of most cohesive soil, and it is probably one of the causes of the longevity of the mound soil pavement in comparison to that of ordinary soils. For $6 \%$ in lime content, the compressive strength reaches its maximal value of $5.95 \mathrm{MPa}$, while the deformation at failure is minimal. Until 28 days of curing, the compressive strength increases almost linearly for all soil-lime mixture. This enhancement could be mostly attributed to the drying of the samples instead of the pozzolanic reactions. Besides, after 12 hours of curing the effect of lime on the shear strength is slightly effective. Therefore, adding lime up to $6 \%$ in content to the termite mound soil should improve its behavior as surface roads.

\section{Conflicts of Interest}

The authors declare no conflicts of interest regarding the publication of this paper.

\section{References}

[1] (2017) National Development Plan 2018-2022 of the Republic of Congo.

[2] Riverson, J., Gaviria, J. and Thriscutt, S. (2002) Rural Roads in SubSaharan Africa, 
Lessons from World Bank Experience. World Bank, Washington DC, Technical Paper, No. 141.

[3] Sangaré, M. and Atiase, S. (1991) Synthesis of Data on the Maintenance and Rehabilitation of Rural Roads in West and Central Africa. African Development Support Project No. 698-0464.28.

[4] Molenaar, A.A.A. (2013) Durable and Sustainable Road Constructions for Developing Countries. Procedia Engineering, 54, 69-81. https://doi.org/10.1016/j.proeng.2013.03.007

[5] Cocks, G., Keeley, R., Leek, C., Foley, P., Bond, T., Crey, A., Paige-Green, P., Emery, S., Clayton, R., Iness and Les Marchant, M.D. (2015) The Use of Naturally Occurring Materials for Pavements in Western Australia. Australian Geomechanics, 50, 43-106.

[6] Weinert, H.H. (1980) The Natural Road Construction Materials of South Africa. Academica, Pretoria, Cape Town.

[7] Biswal, D.R., Sahoo, U.C. and Dash, S.R. (2016) Characterization of Granular Lateric Soils as Pavement Material. Transportation Geotechnics, 6, 108-122.

https://doi.org/10.1016/j.trgeo.2015.10.005

[8] Mahalinga-Iyer, U. and Williams, D.J. (1997) Properties and Performance of Lateritic Soil in Road Pavements. Engineering Geology, 46, 71-80. https://doi.org/10.1016/S0013-7952(96)00096-8

[9] Paige-Green, P., Pinard, M. and Netterberg, F. (2015) A Review of Specifications for Lateritic Materials for Low Volume Roads. Transportation Geotechnics, 5, 86-98. https://doi.org/10.1016/j.trgeo.2015.10.002

[10] Abe, S.S., Yamamoto, S. and Wakatsuki, T. (2009) Soil-Particle Selection by the Mound-Building Termite (Macrotermes bellicosus) on a Sandy Loam Soil Catena in a Nigerian Tropical Savanna. Journal of Tropical Ecology, 25, 449-452. https://doi.org/10.1017/S0266467409006142

[11] Jouquet, P., Tessier, D. and Lepage, M. (2004) The Soil Structural Stability of Termite Nests: Role of Clays in Macrotermes bellicosus (Isoptera, Macrotermitinae) Mound Soils. European Journal of Soil Biology, 40, 23-29. https://doi.org/10.1016/j.ejsobi.2004.01.006

[12] Attoh-Okine, N.O. (1995) Lime Treatment of Laterites and Gravel Revisited. Construction and Building Materials, 9, 283-287. https://doi.org/10.1016/0950-0618(95)00030-I

[13] SETRA/LCPC (2007) Technical Guide Soil Treatment with Lime and/or Hydraulic Binders-Roadbed Application.

[14] Boardman, D.I., Glendinning, S. and Rogers, C.D.F. (2001) Development of Stabilisation and Solidification in Lime-Clay Mixes. Geotechnique, 51, 533-543. https://doi.org/10.1680/geot.2001.51.6.533

[15] Bell, F.G. (1996) Lime Stabilization of Clay Minerals and Soils. Engineering Geology, 42, 223-237. https://doi.org/10.1016/0013-7952(96)00028-2

[16] Maubec, N., Deneele, D. and Ouvrard, G. (2017) Influence of the Clay Type on the Strength Evolution of Lime Treated Material. Applied Clay Science, 137, 107-114. https://doi.org/10.1016/j.clay.2016.11.033

[17] Lemaire, K., Deneele, D., Bonnet, S. and Legret, M. (2013) Effects of Lime and Cement Treatment on the Physicochemical, Microstructural and Mechanical Characteristics of a Plastic Silt. Engineering Geology, 166, 255-261. https://doi.org/10.1016/j.enggeo.2013.09.012 
[18] Experimental Centre for Research and Studies in Building and Public Works (CEBTP) (1980) Practical Guide to Pavement Sizing for Tropical Countries.

[19] de Carvalho, J.C., de Rezende, L.R., Cardoso, F.B.F., Lucena, L.C.F.F.L., Guimaraes, R.C. and Valencia, Y.G. (2015) Tropical Soils for Highway Construction: Pecularities and Considerations. Transportation Geotechnics, 5, 3-19.

https://doi.org/10.1016/j.trgeo.2015.10.004

[20] Nkomo, L.S., Desai, S.A., Seutloali, K.E., Peerbhay, K.Y. and Dube, T. (2019) Assessing the Surface Material Quality of Unpaved Rural Roads to Understand Susceptibility to Surface Deterioration. A Case Study of Four Rural Areas in KwaZulu-Natal, South Africa. Physics and Chemistry of the Earth, 112, 3-11. https://doi.org/10.1016/j.pce.2019.04.005

[21] Islam, S., Hoque, N.M.R., Haque, M.A., Mishra, P.N., Mamun, M.M.H. and Dey, S. (2019) Strength Development in Fine-Grained Paddy Field Soil by Lime Addition. Journal of Building Engineering, 26, Article ID: 100857. https://doi.org/10.1016/j.jobe.2019.100857

[22] Sharma, L.K., Sirdesai, N.N., Sharma, K.M. and Singh, T.N. (2018) Experimental Study to Examine the Independent Roles of Lime and Cement on the Stabilization of a Mountain Soil: A Comparative Study. Applied Clay Science, 152, 183-195. https://doi.org/10.1016/j.clay.2017.11.012

[23] Youssef, N.A.R., Maaitah, O.N. and Qdeshat, K. (2012) Soil Stabilization by Lime. Electronic Journal of Geotechnical Engineering, 17, 1747-1757.

[24] Millogo, Y., Hajjaji, M. and Ouedraogo, R. (2007) Microstructure and Physical Properties of Lime-Clayey Adobe Bricks. Construction and Building Materials, 22, 2386-2392. https://doi.org/10.1016/j.conbuildmat.2007.09.002

[25] Bruce, D.A. (2001) Practitioners Guide to the Deep Mixing Method. Ground Improvement, 5, 95-100. https://doi.org/10.1680/grim.2001.5.3.95 